Seneca the Elder and his Rediscovered Historiae ab initio bellorum civilium 



\section{Seneca the Elder and his Rediscovered Historiae ab initio bellorum civilium}

New Perspectives on Early-Imperial Roman Historiography

Edited by

Maria Chiara Scappaticcio 
The research leading to these results and their publication in Open Access have received fundings from the European Research Council (ERC) under the European Union's Horizon 2020 research and innovation program, within the ERC-StG project PLATINUM (no. 636983), University of Naples 'Federico Il' - Principal Investigator: Maria Chiara Scappaticcio.

ISBN 978-3-11-068585-5

e-ISBN (PDF) 978-3-11-068866-5

e-ISBN (EPUB) 978-3-11-068880-1

\section{(cc) BY-NC-ND}

This work is licensed under the Creative Commons Attribution-NonCommercialNoDerivatives 4.0 International License. For details go to http://creativecommons.org/licenses/ by-nc-nd/4.0/.

\section{Library of Congress Control Number: 2020936587}

\section{Bibliographic information published by the Deutsche Nationalbibliothek}

The Deutsche Nationalbibliothek lists this publication in the Deutsche Nationalbibliografie; detailed bibliographic data are available on the Internet at http://dnb.dnb.de.

(C) 2020 Maria Chiara Scappaticcio, published by Walter de Gruyter GmbH, Berlin/Boston Cover image: Drawing of the subscriptio of P.Herc. 1067 @ École Pratique des Hautes Études (EPHE, Paris), Legs Marichal

Printing and binding: $\mathrm{CPI}$ books $\mathrm{GmbH}$, Leck

www.degruyter.com 